\title{
KEWENANGAN SATPAM SEBAGAI TENAGA KEAMANAN DI PERUSAHAAN
}

\author{
Sudahnan \\ Fakultas Hukum Universitas Wijaya Kusuma Surabaya \\ e-mail: sudah_nan66@yahoo.com
}

\begin{abstract}
ABSTRAK
Satpam mempunyai peran yang sangat penting sebagai tenaga keamanan untuk menjalankan tugas dan kewajibannya untuk membantu peran fungsi Polri di perusahaan dalam mengantisipasi setiap gangguan kamtibmas dalam hal terjadi pelanggaran dan tindakan kejahatan di tempat kerjanya, sehingga diperlukan petugas satpam yang mempunyai kemampuan (skill) dan intelegensi (kecerdasan) yang lebih baik, maka diperlukan pendidikan dan pelatihan satpam agar dapat bertanggung jawab terhadap tugas dan kewajibannya dan dapat bertindak lebih cepat dan efektif dalam kewenangannya sebagai pengamanan fisik yang sifatnya terbatas dan nonjustice di perusahaan.
\end{abstract}

Kata kunci: satpam, tenaga keamanan.

\begin{abstract}
A Security guards have an inportant role as a security Staff to carry out their responsibility for helping Indonesia Police's task in anticipatiey every violation and crime in their work place. It needs a security guards who have good ability and intelegence, so education and training for them are needed to produce a responsible personality foward their tasks, in order to take measure quicker and more effective in their in their limited and unjustice authority as security staff in a company.
\end{abstract}

Keywords: security, security staff.

\section{PENDAHULUAN}

Kemajuan di suatu negara akan terukur dari situasi dan kondisi keamanannya sebagai salah satu syarat utama, baik negara maju, negara berkembang tidak terkecuali negara miskin, faktor keamanan merupakan suatu landasan yang sangat kuat sebagai tolok ukur untuk mendukung terhadap perkembangan yang lainnya, bahkan setiap kebijakan suatu negara akan selalu berhubungan erat dengan situasi dan kondisi yang dipengaruhi oleh faktor dan terciptanya keamanan, seperti pembangunan yang akan dilaksanakan agar segera terealisasi dan cepat terlaksana.

Keamanan merupakan kunci dalam setiap pelaksanaan pembangunan yang akan dilaksanakan, apabila keamanan benar-benar kondusif, maka pelaksanaan roda perekonomian dan pembangunan akan berjalan dan terlaksana dengan baik dan tepat waktu sesuai dengan yang direncanakan.

Pemerintah Indonesia telah memberikan jabaran yang luas untuk menciptakan keamanan di dalam negeri, hal ini tercantum dalam Pembukaan Undang-Undang Dasar 1945 alinea keempat, dan dalam Ketetapan Majelis Permusyawaratan Rakyat Republik Indonesia No. IV/MPR/1999 tentang Garis- garis Besar Haluan Negara 1999-2004 dalam huruf I angka 2 tentang Pertahanan dan Keamanan, serta dalam Amandemen Ke-IV Undang-Undang Dasar 1945 Bab XII tentang Pertahanan dan Keamanan Negara, Pasal 30 ayat (1).

Bertitik tolak dari antisipasi Pemerintah Indonesia dalam mengantisipasi keamanan dalam negeri agar terciptanya rasa aman dalam masyarakat, maka fungsi Kepolisian menjadi tolok ukur keamanan di suatu lingkungan masyarakat, sehingga peranan Polri dituntut untuk meningkatkan profesionalisme di setiap jajaran kepolisian baik di Pusat maupun Daerah sebagaimana yang diatur dalam Undang-Undang Republik Indonesia Nomor 2 Tahun 2002 tentang Kepolisian Negara Republik Indonesia, bahwa tugas dan fungsi Kepolisian bukan hanya sebagai pemeliharaan keamanan, ketertiban masyarakat dan penegak hukum saja tetapi lebih jauh dari hal itu dapat mengeliminir semaksimal mungkin setiap gangguan Kamtibmas, dan penegakan hukum benar-benar dapat dilaksanakan sehingga bisa membantu jalannya roda perekonomian dan terlaksananya pembangunan dengan baik, "Polri selaku pengemban fungsi kepolisian dan fungsi Pemerintahan Negara di bidang 
pemeliharaan keamanan dan ketertiban masyarakat, penegakan hukum, perlindungan, pengayoman dan pelayanan kepada masyarakat, telah berupaya seoptimal mungkin guna mencegah terjadinya gangguan kamtibmas dengan lebih mengedepankan tindakan preemptif dan preventif dengan harapan dapat mengurangi atau mengeliminir setiap bentuk gangguan kamtibmas yang kondusif dan pada gilirannya dapat menunjang roda pembangunan dan perekonomian bangsa kita yang masih belum keluar dari berbagai krisis yang melandanya". (Amanat Kapolri, Majalah (AMSI), Edisi 02 Maret 2003:7).

Keamanan di dalam masyarakat bukan hanya tugas dan tanggungjawab pihak Kepolisian saja, tetapi seluruh lapisan masyarakat mempunyai peran dan andil yang sangat besar agar tercipta keamanan di daerah lingkungannya, peran serta ini sangat penting bagi masyarakat itu sendiri, apabila dirunut dari keterbatasan aparat Kepolisian yang tidak mungkin mampu melayani semua tugas-tugas yang menjadi kewajibannya disamping itu jumlah aparat kepolisian yang belum bisa untuk melayani seluruh tugas-tugas yang menjadi tanggungjawabnya, apabila diperhatikan dari wilayah negara Indonesia yang sangat luas dan terdiri dari beribu-ribu pulau disertai dengan jumlah penduduk Indonesia yang terus mengalami pertambahan dari tahun ke tahun sedangkan jumlah aparat kepolisian tidak seban-ding dengan keadaan tersebut. Untuk itu tugas dan fungsi tersebut dapat diambil alih oleh masyarakat itu sendiri di dalam lingkungannya, “... Polri sebagai inti pembina kamtibmas secara kuantitatif tidak pernah akan mampu menutup luasnya wilayah dan banyaknya jumlah penduduk dan gangguan kamtibmas. Dengan potensi masyarakat seperti halnya security Astra Group yang profesional jelas membawa dampak positif bagi pencegahan maupun penanggulangan kejahatan, terutama di tempat atau di lingkungan kita bekerja." (Darwan Siregar, Majalah (AMSI), Edisi 01 Oktober 2002:30). Dan di dalam Pasal 3 ayat (1) huruf C Undang-Undang Republik Indonesia Nomor 2 Tahun 2002 tentang Kepolisian Negara Republik Indonesia, mengenai bentuk-bentuk pengamanan swakarsa.

Keamanan juga dapat dilakukan oleh petugas satpam pada waktu bertugas di lingkungan tempat kerjanya untuk membantu peran fungsi Polri agar tempat kerjanya tercipta rasa aman dari segala gangguan kamtibmas. Peran dan fungsi petugas satpam dalam melaksanakan tugas di lingkungan tempat kerjanya apabila dilihat dari dimensi kepolisian merupakan bentuk sosiologis fungsi kepolisian yang tumbuh dan berkembang dalam tata kehidu- pan masyarakat akan pentingnya keamanan dan ketertiban di lingkungan masing-masing, juga dapat dipandang sebagai refleksi masyarakat dalam mewujudkan mempolisikan dirinya dan diharapkan mengarah kepada pemolisian masyarakat yang dilandasi akan kesadaran di daerah lingkungannya, "Sebagai warga juga diharapkan untuk menerapkan sistem Swakarsa agar kita tidak mudah terhasut di dalam issuissu yang mengakibatkan tindakan yang merugikan sambil terus berupaya menciptkan keamanan dengan hidup yang penuh kesadaran dengan sistem "polisi bagi diri sendiri”. (Majalah (AMSI) Edisi 01 Oktober 2002:7). Dijelaskan juga oleh Presiden dalam pidatonya dalam menghadapi teror "Masalah keamanan bukan hanya tugas aparat keamanan saja tetapi semua lapisan masyarakat ikut serta untuk menanggulangi dan ikut menjaga lingkungannya yang patut dicurigai”. (Presiden Megawati, Liputan 6 SCTV, 9 September 2004, jam 18.00)

Situasi politik dan ekonomi yang berdampak sangat serius terhadap situasi dan kondisi keamanan akan mempengaruhi keadaan dalam tata kehidupan masyarakat, proses itu memerlukan dukungan dari setiap lapisan masyarakat tidak ada kecualinya agar keamanan yang diharapkan bisa tetap terjaga, meskipun pada prinsipnya dalam pelaksanaannya sangat sulit disebabkan oleh adanya beberapa faktor kepentingan dalam masyarakat, "Kondisi keamanan bangsa yang terjadi akibat dari krisis yang berkepanjangan dan berbagai macam tuntutan yang bergerak tanpa kendali disertai dengan tindakan-tindakan anarkis seperti pengrusakan, penganiayaan, pembakaran dan bahkan peledakan bom. Disebutkan bahwa tindakan tersebut merupakan perbuatan yang anomali dan bertentangan dengan budaya bangsa dan Hukum Negara". (Majalah (AMSI) Edisi 01 Oktober 2002:8)

Keamanan sangat diperlukan juga pada sektorsektor bidang usaha atau bisnis di Perusahaan Negara maupun Perusahaan Swasta untuk mengantisipasi dan menjaga keamanan di sektor usahanya, pihak perusahaan telah melakukan langkah-langkah dengan melakukan perekrutan dan penempatan petugas satpam. Satpam menjadi ujung tombak di Perusahaan agar tidak sampai terjadi suatu gangguan yang akan merugikan kinerja perusahaan dalam menjalankan bidang usahanya, baik yang bersifat ke dalam perusahaan yang disebabkan oleh buruh seperti; demostrasi, mogok kerja, dan orasi terbuka, unjuk rasa pekerja, maupun yang bersifat keluar yang disebabkan pengacau yang datangnya dari luar seperti; perampok, maling, teror maupun sabotase, "Kehadiran Polri tidaklah mungkin berada di setiap tempat dalam waktu 
yang bersamaan karena cukup banyak sekali lingkungan yang belum dapat disentuh secara intensif oleh Polri. Untuk kepentingan intensitas keberadaan Polri inilah diperlukan bantuan dan keberadaan keamanan swakarsa, oleh masyarakat, untuk dan dari masyarakat diwadahi dalam bentuk-bentuk pengamanan swakarsa antara lain satpam. Satpam sebagai salah satu bentuk pengamanan ... satpam adalah pembantu pengemban fungsi kepolisian" (Majalah (AMSI) Edisi 01 Oktober 2002:26).

Pendidikan dan pelatihan satpam agar meningkatkan kemampuan (skill) dan intelegensi (kecerdasan) petugas satpam akan memegang peranan dalam memberikan transfer ilmu pengetahuan yang sesuai dengan bidangnya sebagai tenaga keamanan, pelaksanaan pendidikan dan pelatihan satpam yang dilaksanakan oleh pemerintah maupun swasta sama-sama bertujuan untuk mencetak petugas satpam yang handal dan mempunyai dedikasi yang tinggi dalam mengantisipasi dan menghadapi semua gangguan kamtibmas yang terjadi, "Usaha mempertinggi keahlian para penganggur dengan jalan memberikan kursus kejuruan dan latihan di tempat latihan kerja, terbentur pula pada kesukaran menempatkan mereka setelah dididik dan dilatih". (Imam Soepomo, 1970:182)

Pendidikan dan pelatihan petugas satpam sudah menjadi kebutuhan yang mendasar dalam hal yang lebih komplek pada saat ini, hal ini didukung dari banyaknya kejadian di dalam Masyarakat terjadinya gangguan kamtibmas, perampokan seorang nasabah Bank yang terjadi di depan petugas satpam di kantor Bank BCA, pembobolan Bank BNI pada waktu dijaga petugas satpam, perampokan seorang Direktur sebuah perusahaan di depan petugas satpam, peledakan bom di Hotel J.W. Marriot pada waktu diperiksa petugas satpam, perampokan seorang nasabah Bank yang dilakukan pada waktu dikawal oleh petugas satpam, perampokan SPBU di Jemursari dan Dupak pada waktu dijaga petugas satpam, peledakan bom di depan Kedutaan Besar Australia di Jalan Kuningan pada waktu dalam penjagaan petugas Satpam dan kejadian-kejadian yang lain yang berhubungan langsung pada peran dan fungsi satpam sebagai tenaga keamanan di Perusahaan, salah satu sebab hal ini terjadi masih banyaknya petugas satpam yang belum dibekali dalam bidang pendidikan dan pelatihan sama sekali, "Keprihatinan AMSI mengenai kondisi Satpam di seluruh Indonesia yang berjumlah 242.000 orang sebagian besar (69\%) belum mengikuti pendidikan dasar kepolisian resmi pola 232 jam, ...." (......, Majalah (AMSI) Edisi 02 Maret 2003:9). Dan dijelaskan oleh Kapolri, "Dilihat dari segi kuan- titas satuan pengamanan di Indonesia saat ini yang mencapai 242.119 orang dan melebihi dari jumlah personel Polri sendiri, menunjukkan suatu jumlah yang besar, dan apabila di-manage secara baik akan memiliki kemampuan yang cukup dahsyat. Namun dari segi kualitas kiranya perlu lebih ditingkatkan lagi mengingat masih banyak anggota satuan pengamanan yang belum memiliki kualifikasi pendidikan dasar satuan pengamanan ...." (Amanat Kapolri, Majalah (AMSI), Edisi 02 Maret 2003:7).

Lembaga Pendidikan dan Pelatihan Satpam yang diadakan oleh Pemerintah maupun swasta sangat dibutuhkan dan sangat efektif untuk melatih dan mendidik calon petugas satpam sebelum ditempatkan dan dipekerjakan di lingkungan tempat kerjanya, seperti: PT. Scoricor, PT. Mahakam Merah Padi, PT. Jaga Raga, PT. Mitra Karya Utama Sentosa, PT. Sigap Prima Astrea (SPA), PT. Group 4 Securitas Indonesia dan lembaga-lembaga pendidikan yang lain. Pasal 1 angka 9, Pasal 9 dan Pasal 13 Undang-Undang Republik Indonesia Nomor 13 Tahun 2003 tentang Ketenagakerjaan (L.N. No. 39 Tahun 2003; Tambahan L.N. No. 4279)

Pendidikan dan Pelatihan satpam sebagai tenaga keamanan di lingkungan perusahaan akan menciptakan petugas satpam yang mempunyai kemampuan (skill) di bidang pekerjaannya dan akan menambah etos kerja serta meningkatkan tingkat intelegensinya (kecerdasan), sehingga akan lebih cepat dan tanggap dalam mengantisipasi setiap gangguan kamtibmas serta permasalahan yang terjadi, dan setiap petugas satpam yang bekerja di perusahaan sungguh-sungguh dapat dipercaya untuk melaksanakan peran dan fungsinya sebagai tenaga keamanan dengan sangat efektif dan penuh tanggung jawab, dan dapat memberikan dorongan semangat serta gairah kerja bagi segenap jajaran anggota petugas satpam di tempat kerjanya yang akhirnya dapat lebih mampu untuk meningkatkan kiprah pengabdiannya kepada perusahaan, negara dan bangsa. Berdasarkan latar belakang yang terurai di atas, Bagaimanakah Peran dan Fungsi serta Kewenangan Satpam sebagai Tenaga Keamanan di Perusahaan? Sehingga dapat mengantisipasi sedini mungkin kemungkinan terjadi tindak kriminal di tempat ia bekerja.

\section{PEMBAHASAN}

Petugas Satpam adalah satuan tenaga keamanan yang berada di tengah-tengah lingkungan masyarakat maupun di lingkungan perusahaan untuk membantu peran fungsi Polri di tempat petugas satpam bekerja; di Perusahaan, Perumahan, Pertokoan, Perhotelan, 
Rumah Sakit dan tempat lainnya, dengan tujuan untuk menjaga ketertiban dan keamanan masyarakat agar terhindar dari segala gangguan kamtibmas. Adanya petugas satpam merupakan bantuan dan partisipasi yang sangat penting dari peran serta masyarakat untuk ikut serta menjaga keamanan agar terciptanya rasa aman di lingkungannya, "Bentuk partisipasi masyarakat sangat banyak dan berbagai macam ragam, beberapa pekerja sukarelawan diberikan kekuasaan menurut hukum melaksanakan fungsinya seakan mereka adalah pegawai pemerintah, adapun sukarelawan yang lain menyambungkan kegiatan pencegahan kejahatan dengan jalan yang kurang formal" (Ilham Gunawan, 1992:64). Serta menurut Frans Magnis Suseno Sj. dan Kees Bertens, dkk: "Pertimbangan ini menunjukkan bahwa manusia ternyata bertanggung jawab terhadap dirinya sendiri, ia adalah Aufgabe: tugas bagi dirinya sendiri, pengembangan diri (self realizetion) merupakan panggilan luhur dan salah satu kewajiban mural dasar bagi manusia, semakin ia berhasil dalam panggilan itu, semakin ia merasa bahagia”. (Franz Magnis Suseno, Sj., Kees Bertens, dkk., 1993:44)

Petugas Satpam pada saat sekarang ini benar-benar sangat efektif sebagai tenaga keamanan di lingkungan tempat kerjanya, disebabkan pada akhir-akhir ini banyak sekali terjadi gangguan kamtibmas di Kota maupun di Desa yang sering mengganggu dan meresahkan masyarakat, sehingga peran serta petugas satpam untuk ikut mengamankan di tempat kerjanya sangat diperlukan sesuai dengan tugas dan fungsi petugas satpam sebagai tenaga keamanan terbatas pada ruang lingkup tempat kerjanya. Rasa aman merupakan suatu kebutuhan pada setiap lapisan masyarakat baik di Kota maupun di Desa, di tempat umum maupun di tempat khusus, di perusahaan negara maupun swasta, perorangan maupun kelompok, di Rukun Tetangga, Rukun Warga, Kelurahan atau Desa, Kecamatan, Kabupaten atau Kota, Propinsi maupun Negara, rasa aman merupakan sebuah dambaan selama manusia masih hidup di dunia, bahkan rasa aman juga sangat diperlukan oleh sebuah perusahaan agar bisnis atau usaha yang dikelola bisa terus berlangsung.

Petugas Satpam sebagai salah satu bentuk kepedulian dari perusahaan untuk membantu fungsi Polri sebagai tenaga keamanan untuk melakukan pengamanan di perusahaan agar bisa menjalankan usaha atau bisnisnya dengan lancar tanpa adanya hambatan dan rintangan dari segala situasi dan kondisi yang bisa merugikan perusahaan, maka keberadaan petugas satpam di perusahaan sangat penting dan sangat diutamakan sebagai ujung tombak perusahaan untuk menunjang semua kegiatan yang ada di perusahaan baik yang bersifat umum; menjaga di dalam lingkungan perusahaan, menjaga ketertiban para pekerja/ buruh perusahaan, mengawasi alat-alat vital perusahaan, maupun yang bersifat khusus; mendampingi petugas perusahaan untuk mengambil atau mengantarkan uang ke atau dari Bank; "Satpam sebagai pembantu pengemban fungsi kepolisian di lingkungan kerjanya diarahkan untuk melaksanakan kegiatan pelayanan keamanan bagi kepentingan suatu perusahaan agar tidak terjadi resiko yang merugikan perusahaan, ...." (A. Hasan, Majalah (AMSI), Edisi 01 Oktober 2002:27). Serta menurut Abdulkadir Muhammad, "... segala kekayaan dan usaha yang terdapat dalam lingkungan perusahaan sebagai satu kesatuan dengan perusahaan, yang digunakan untuk memperoleh keuntungan yang sebesar-besarnya dengan pengorbanan yang sekecil-kecilnya, ...." (Abdulkadir Muhammad, 1999:223).

Peranan petugas satpam di perusahaan sangat penting untuk menjaga kelangsungan dan kestabilan bisnis atau usaha yang dijalankan perusahaan, apabila petugas satpam betul-betul atau sungguh-sungguh melaksanakan peran dan fungsinya maka kelangsungan usaha atau bisnis perusahaan akan lancar tanpa suatu hambatan, tetapi bila peran petugas satpam tidak mampu berbuat dengan semestinya, maka kelangsungan usaha atau bisnis perusahaan akan terganggu dan akan menimbulkan kerugian baik materiil maupun non materiil pada perusahaan yang tidak sedikit, "Pemahaman AMAN itu MAHAL, dan LEBIH MAHAL KALAU TIDAK AMAN, hal ini sedang terus disosialisasikan kepada masyarakat luas, terlebih kepada perusahaan-perusahaan yang memiliki dan mengelola asset milliaran rupiah dan bahkan trilliun rupiah, agar jangan semata-mata biaya keamanan itu menjadi suatu biaya, tapi timbulkan pengertian bahwa aman itu harus merupakan bagian dari investasi yang harus dipedulikan suasananya yaitu sejuk, damai dan tentram. Sehingga kepada para pengusaha atau para pemimpin perusahaan, harus sudah mulai dari sekarang ke depan untuk memikirkan bahwa "bagaimana caranya untuk mengusahakan agar para security yang ada sekarang di masing-masing perusahaan atau proyek vital agar menjadi lebih profesional dan berdaya untuk mencegah adanya suatu gangguan yang mengakibatkan suasana tidak aman!" Karena telah terbukti bahwa ada beberapa perusahaan atau instansi yang sudah memiliki security yang profesional, yaitu dari sikap dalam menjalankan tugasnya dan penampilannya secara umum jauh berbeda, 
dan mampu mengantisipasi situasi dan permasalahan, sehingga terkesan di perusahaan tersebut sangat tertib dan teratur". (IGK. Sastrawan, Majalah (AMSI), Edisi 02 Maret 2003:54.).

Keamanan di perusahaan benar-benar sangat diperlukan, oleh karena itu dibutuhkan petugas satpam yang benar-benar telah menempuh pendidikan dan pelatihan satpam, bekal pengalaman dan pengetahuan di bidang pendidikan dan pelatihan satpam akan lebih optimal dan efektif dari sebelumnya. Adanya petugas satpam yang sudah mendapatkan pembinaan di bidang pendidikan dan pelatihan yang sungguh-sungguh akan dapat menambah etos dan produktivitas kerja yang lebih baik terhadap kinerja petugas satpam, setiap tindakan yang dilaksanakan akan dilakukannya secara profesional sesuai dengan bidang kerja sebagaimana telah diembannya, "Profesionalisme sebenarnya adalah watak yang didasari oleh rasa percaya diri yang tinggi dari pelakunya karena itu profesionalisme berarti bekerja dengan kompetensi memadai, dengan tenang dan penuh percaya diri”. (Philip Davis ditulis oleh Willian Buntoro, Majalah (AMSI), Edisi 02 Maret 2003:43).

Undang-Undang Republik Indonesia Nomor 13 Tahun 2003 tentang Ketenagakerjaan, telah menggariskan bahwa "Pembinaan pelatihan kerja dan pemagangan ditujukan ke arah peningkatan relevansi, kualitas, dan efisiensi penyelenggaraan pelatihan keja dan produktivitas". Dan peningkatan tersebut dilakukan melalui pengembangan budaya produktif, etos kerja, teknologi, dan efisiensi kegiatan ekonomi, menuju terwujudnya produktivitas nasional". Hal ini dipertegas dalam Pasal 15 ayat (2) huruf G Undang-Undang Republik Indonesia Nomor 2 Tahun 2002 tentang Kepolisian Republik Indonesia, bahwa Kepolisian sebagai pengemban amanat untuk mendidik dan melatih petugas satpam akan "Memberikan petunjuk, mendidik, dan melatih aparat kepolisian khusus dan petugas pengamanan swakarsa dalam bidang teknis kepolisian".

Menurut penulis sekarang masih banyak perusahaan yang mempekerjakan petugas satpam yang belum dibekali di bidang pendidikan dan pelatihan sama sekali sebagai tenaga keamanan di tempat kerjanya, dan bahkan masih banyak perusahaan yang kurang memperhatikan tentang pentingnya petugas satpam di perusahaan, hal ini masih banyaknya petugas satpam dinomerduakan di perusahaan, padahal petugas satpam yang dibekali pendidikan dan pelatihan akan mempunyai keahlian dan secara langsung akan membantu kelancaran dan kelangsungan usaha atau bisnis perusahaan, "Dalam sejumlah kasus, masih ada manajemen perusahaan yang mengorganisir fungsi security hanya sebagai pelengkap fungsi pelayanan kantor saja, asal ada tanpa perencanaan yang seharusnya. Fungsi security harus dikategorikan bukan sebagai fungsi pelengkap pelayanan kantor, melainkan merupakan fungsi supporting dari alur organisasi perusahaa. Dalam banyak kejadian sejumlah perusahaan membentuk fungsi pengamanan dimulai secara bertahap dan yang lebih dahulu dilakukan dengan memasang kunci-kunci pintu, memberi penerangan yang baik, memasang alarm gedung, dan lain sebagainya, lebih mengutamakan dan mengandalkan perangkat keras terlebih dahulu, dibandingkan dengan mempersiapkan sumber daya manusia (SDM). Yang terjadi dalam sejumlah kasus, pembentukan fungsi keamanan dalam sebuah perusahaan yang bersifat strategis manajerial. Sementara pendekatan reaktif atau bertahap dapat berkembang menjadi sebuah fungsi pengamanan yang efektif untuk mencegah timbulnya risiko ancaman atau bahaya bagi perusahaan, sehingga usaha-usaha dari fungsi security dilaksanakan secara optimal dan sungguh-sungguh untuk mengantisipasi timbulnya risiko yang belum kita ketahui sebelumnya, kita akan merasa aman karena kita mengantisipasi risiko sekecil apapun". (William Buntoro, Majalah (AMSI), Edisi 02 Maret 2003:42)

Perusahaan yang mempekerjakan petugas satpam yang telah dibekali pendidikan dan pelatihan sudah pasti mempunyai etos dan produktivitas kerja yang lebih efektif dan lebih baik serta menguasai keterampilan yang baik dan handal, mempunyai keuletan dalam bekerja dan bisa dipastikan akan sungguh-sungguh akan menjaga area atau lingkungan perusahaan dengan rasa tanggungjawab serta mempunyai disiplin tinggi pada waktu melakukan tugas dan fungsinya untuk mengatasi segala gangguan kamtibmas.

Kewenangan petugas satpam di perusahaan akan benar-benar dituntut di bidang keahlian dan pengalamannya serta keuletannya pada saat bekerja sehingga petugas satpam waktu melaksanakan tugas dan fungsinya sebagai tenaga keamanan bisa melaksanakannya dengan baik dan benar dalam ruang lingkup di lingkungan perusahaan tempat kerjanya agar tidak sampai terjadi sesuatu yang tidak diinginkan atau diharapkan oleh perusahaan sehingga mengakibatkan timbulnya suatu kerugian dan pada akhirnya akan mengganggu pada kelangsungan bisnis atau usaha perusahaan, sehingga keberadaan petugas satpam benar-benar membawa manfaat pada perusahaan maupun karyawannya, "Salah satu tugas utama dari anggota aparat keamanan adalah menjaga keamanan perusahaan dan kenyamanan karyawannya. Para aparat keamanan 
pun mempunyai "power" yang dapat dimanfaatkan secara positif dan bila mereka mampu mempengaruhi masyarakat sekeliling ke arah yang positif, pasti mereka akan berperilaku positif pula”. (Sri Dahana, Majalah (AMSI), Edisi 01 Oktober 2002:9)

Kewenangan petugas satpam yang sedang melaksanakan tugasnya perlu diberikan rambu-rambu dan batasan agar tidak melampaui tugas dan fungsi Polri yang mempunyai kewenangan dan ruang lingkup hukum publik, sehingga kewenangan petugas satpam benar-benar berfungsi sebagai tenaga keamanan dalam rangka menegakkan hukum hanya meliputi ruang lingkup di perusahaan. Dalam UndangUndang Republik Indonesia Nomor 2 Tahun 2002 tentang Kepolisian Negara Republik Indonesia ditegaskan bahwa Kepolisian benar-benar melakukan tugasnya dalam "melakukan koordinasi, pengawasan, dan pembinaan teknis terhadap kepolisian khusus, penyidik pegawai negeri sipil, dan bentukbentuk pengamanan swakarsa". Sedangkan tata cara pelaksanaan kepolisian dalam melaksanakan tugasnya kepada petugas satpam akan diatur dengan ketentuan Peraturan Pemerintah dan sampai sekarang peraturan tersebut belum dibuat.

Menurut penulis kewenangan petugas satpam di lingkungan tempat kerjanya dapat melakukan tindakan-tindakan secara terbatas yang perlu dilaksanakan saat melakukan tugasnya dalam hal terjadi gangguan di perusahaan sebagai peran pembantu fungsi Polri, antara lain:

\section{Sebagai Petugas Keamanan}

Petugas satpam yang bertugas di lingkungan perusahaan sebagai petugas keamanan untuk membantu peran fungsi Polri, sehingga dapat mengantisipasi setiap gangguan yang akan terjadi dan bertindak lebih cepat dan tepat untuk memberikan informasi; Kitab Undang-Undang Hukum Acara Pidana No. 8 Tahun 1981 menjelaskan bahwa "Setiap orang yang mengalami, melihat, menyaksikan dan atau menjadi korban peristiwa yang merupakan tindak pidana berhak untuk mengajukan laporan atau pengaduan kepada penyelidik dan atau penyidik baik lisan maupun tertulis", demikian juga seorang petugas satpam juga berhak untuk melaporkan setiap kejadian tindak pidana yang terjadi di tempat kerjanya. Dan "Setiap orang yang mengetahui permufakatan jahat untuk melakukan tindak pidana terhadap ketentraman dan keamanan umum atau terhadap jiwa atau terhadap hak milik wajib seketika itu juga melaporkan hal tersebut kepada penyelidik atau penyidik". Petugas satpam yang bertugas di lingkungan tempat kerjanya dapat dikategorikan mempunyai dua kewenangan; a. Secara Pre-emtif (membina, mengarahkan);

Petugas satpam saat melaksanakan tugasnya mempunyai kewenangan untuk membina dan mengarahkan bahkan menyuruh dan mengajak setiap orang atau individu yang ada di lingkungan kerjanya untuk melakukan atau tidak melakukan sesuatu pekerjaan atau perbuatan, dan terus-menerus mengarahkan atau membimbing ke arah yang lebih baik dan memberikan contoh teladan yang lebih baik di lingkungan pekerjaannya, seperti: memberitahukan kepada pekerja atau buruh agar tidak melakukan atau mengulangi perbuatannya yang tidak sesuai dengan peraturan di perusahaan, dan lainnya. Dengan kewenangan yang telah diberikan ini, maka tercipta ketertiban di perusahaan.

b. Secara Preventif (mencegah, menangkal);

Petugas satpam saat melaksanakan tugasnya mempunyai kewenangan menjaga atau mengamankan perusahaan agar tidak sampai terjadi suatu gangguan kamtibmas serta tindak pidana kejahatan atau pelanggaran di lingkungan kerjanya dengan jalan mempersiapkan atau menyediakan beberapa peralatan pengamanan atau perlindungan yang berhubungan langsung atau tidak langsung dengan keamanan perusahaan. Petugas satpam akan melaksanakan segala usaha dan upaya demi kelangsungan usaha atau bisnis perusahan agar tetap berlangsung dengan baik dan dapat menjalankan kegiatan dalam rangka menyelenggarakan dan melindungi lingkungan perusahaan dan aset-aset perusahaan maupun pekerja atau buruh perusahaan, sehingga keamanan pekerja atau buruh dan lingkungan perusahaan tetap berjalan sebagaimana mestinya tanpa ada gangguan yang akan merugikan perusahaan, seperti: mengontrol lingkungan perusahaan dengan bergantian setiap dua jam sekali, dan lainnya.

\section{Sebagai Petugas Penegakan Hukum Terbatas}

Petugas satpam saat melaksanakan tugasnya di perusahaan mempunyai kewenangan dan berperan sebagai petugas penegakan hukum terbatas untuk membantu peran fungsi Polri, yaitu; Secara Represif Non Yustisiil (menindak, menangkap, memborgol, melakukan introgasi awal), sehingga petugas satpam mempunyai kewenangan dapat menindak atau menangkap, menggeledah, memborgol, mengintrogasi yang sifatnya sementara dan terbatas sebelum diserahkan kepada Kepolisian bila terjadi tindak pidana kejahatan atau pelanggaran di perusahaan baik yang dilakukan oleh pekerja maupun orang lain, maka petugas satpam dapat melakukan tindakan-tindakan yang dianggap tepat agar pelakunya dapat cepat 
ditangani, kewenangan yang dilakukan oleh petugas satpam hanyalah merupakan tindakan awal agar pelaku tidak melarikan diri atau tidak menimbulkan dampak yang lebih besar kepada perusahaan dan menghindari jangan sampai terjadi ada pihakpihak yang main hakim sendiri, kemudian pelaku yang sudah tertangkap tangan secepatnya diserahkan kepada pihak Polri setempat yang mempunyai hak dan kewenangan untuk menyelidiki dan menyidik serta menahan pelaku kejahatan atau pelanggaran yang telah dilakukan, tindakan petugas satpam bisa dilakukan bila terjadi tindak pidana yang tertangkap tangan, sehingga kewenangan petugas satpam dapat melakukan tindakan upaya paksa untuk menegakkan hukum di lingkungan kerjanya yang sifatnya sementara, Pasal 1 angka 19 dan 111 ayat (1) No. 8 Tahun 1981 Kitab Undang Undang Hukum Acara Pidana, yang dikatakan tertangkap tangan; a. Tertangkapnya seseorang pada waktu sedang melakukan tindak pidana; b. Atau dengan segera sesudah beberapa saat tindak pidana itu dilakukan; c. Atau sesaat kemudian diserukan oleh khalayak ramai sebagai orang yang melakukan; d. Sesaat kemudian padanya ditemukan benda yang diduga keras telah dipergunakan melakukan tindak pidana yang menunjukkan bahwa ia adalah pelakunya atau turut melakukan atau membantu melakukan tindak pidana.

Demikian juga yang dilakukan oleh petugas satpam yang bertugas di tempat kerjanya apabila pada bertugas ada pelaku kejahatan yang tertangkap tangan maka setiap orang berhak, sedangkan setiap orang yang mempunyai wewenang dalam tugas ketertiban, ketentraman dan keamanan umum wajib, menangkap tersangka guna diserahkan beserta atau tanpa barang bukti kepada penyelidik atau penyidik".

Menurut penulis kewenangan Petugas Satpam sebagai tenaga keamanan dan penegakan hukum di lingkungan perusahaan tempat kerjanya apabila terjadi tindak pidana yang tertangkap tangan, harus benar-benar memperhatikan hal-hal sebagai berikut: a. Tidak bertentangan dengan suatu aturan hukum; $b$. Selaras dengan kewajiban hukum yang mengharuskan tindakan tersebut dilaksanakan; c. Harus patut, masuk akal, termasuk dalam lingkup kewenangannya; d. Pertimbangan yang layak berdasarkan keadaan yang memaksa dan menghormati hak-hak asasi manusia.

Kewenangan petugas satpam pada waktu melaksanakan tugas umumnya sama dengan yang dilakukan oleh Polri, tetapi pada tingkatan prinsipilnya pelaksanaan tugas dan fungsi yang dilakukan oleh petugas satpam ada perbedaannya kewenangan, kewenangan yang dilaksanakan oleh petugas satpam pada dasarnya hanya diperbolehkan melakukan pengamanan phisik dan penegakan hukum phisik di tempat kerjanya tanpa mempunyai kewenangan menyidik dan menahan. Dan kewenangan yang dimiliki petugas satpam sifatnya hanya terbatas di lingkungan perusahaan tempat kerjanya, "Kewenangan kepolisian terbatas yang dimiliki oleh anggota security, di dalam forum tersebut dijelaskan bahwa security memiliki kewenangan Preemtif (membina, mengarahkan), Preventif (mencegah, menangkal) dan Represif (menindak), yang sifatnya terbatas dan non justice, sebatas untuk kepentingan perusahaan saja, sebagai contoh seorang karyawan tertangkap tangan maka security berwenang memeriksa dan menggeledah karyawan tersebut hanya untuk kepentingan internal pengamanan perusahaan bukan untuk diteruskan kepada penuntut umum" (Doyo Pramono, Majalah (AMSI), Edisi 02, Maret 2003:49). Dan Menurut Rony Hanintijo Soemitro, "Mekanisme pengendalian sosial ini berupa suatu proses yang telah direncakan lebih dahulu dan bertujuan untuk menganjurkan, mengajak, menyuruh atau bahkan memaksa anggota-anggota masyarakat agar supaya mematuhi norma-norma hukum atau tata tertib hukum yang sedang berlaku". (Ronny Hanintijo Soemitro, 1984:4)

Bentuk kewenangan terbatas yang diberikan pada petugas satpam di perusahaan merupakan suatu aturan yang harus dipatuhi dan dipahami serta dilaksanakan dengan prosedur yang benar meskipun hanya mempunyai ruang lingkup kewenangan kuasa tempat dan tidak memiliki ruang lingkup kewenangan kuasa yang termasuk kewenangan hukum publik, seperti; menuntut, menyidik maupun menahan, hal ini ditegaskan di dalam Penjelasan Pasal 3 huruf c Undang-Undang Republik Indonesia Nomor 2 Tahun 2002 tentang Kepolisian Negara Republik Indonesia, bahwa petugas satpam merupakan "bentuk-bentuk pengamanan swakarsa" adalah suatu bentuk peng-amanan yang diadakan atas kemauan, kesadaran, dan kepentingan masyarakat sendiri yang kemudian memperoleh pengukuhan dari Kepolisian Negara Republik Indonesia, seperti satuan pengamanan lingkungan dan badan usaha di bidang jasa pengamanan. Bentuk-bentuk pengamanan swakarsa memiliki kewenangan Kepolisian Negara terbatas dalam "Lingkungan kuasa tempat" (teritoir gebied/ruimte gebied) meliputi lingkungan pemukiman, lingkungan kerja, lingkungan pendidikan. Contohnya adalah satuan pengamanan lingkungan di pemukiman, satuan pengamanan pada kawasan perkantoran atau satuan pengamanan pada pertokoan.

Pengaturan mengenai pengamanan swakarsa merupakan kewenangan Kapolri, dan dipertegas 
oleh Kapolri di dalam surat keputusannya Nomor Pol: Skep/1017/XII/2002 tentang Kurikulum Pelatihan Satuan Pengamanan, angka 1 dalam konsideran Pertimbangannya terutama di bidang penegakan hukum, hal ini dipertegas lagi di dalam UU Republik Indonesia Nomor 2 Tahun 2002 tentang Kepolisian Negara Republik Indonesia, Penjelasan Pasal 15 ayat (1) huruf K tentang Kewenangan Polisi Memberikan Izin, dipertegas juga di dalam Undang-Undang No. 12 Tahun 1951 tentang Senjata Api dan Bahan Peledak dalam Pasal 1 ayat (1), Pasal 5 ayat (2), bagi petugas satpam yang dilengkapi senjata api atau senjata tajam waktu melaksanakan tugasnya harus terlebih dahulu mendapatkan izin dari Polri.

Kewenangan petugas satpam sebagai tenaga keamanan terbatas dalam melaksanakan tugasnya sebagai peran pembantu Polri menurut penulis sudah mempunyai cakupan yang lebih luas untuk mengantisipasi dan mengendalikan setiap gangguan kamtibmas dan tindak pidana kejahatan atau pelanggaran yang akan terjadi di Perusahaan, kewenangan itu tidak berbeda dengan kewenangan yang dimiliki dan dilakukan oleh aparat Kepolisian dan tentara hal yang menjadi perbedaannya menurut penulis terletak dalam tingkat kewenangan penyidikan dan penuntutan yang tidak bisa dilakukan oleh petugas satpam demikian juga mengenai kelembagaan petugas tenaga satpam yang statusnya ditangani oleh pihak swasta sedangkan aparat kepolisian kelembagaannya ditangani oleh negara, "Hampir semua "ilmu" yang dimiliki polisi atau tentara telah dikuasai "aparat" swasta ini. Formance para SO juga mirip apa yang asli itu. Bahkan, sejumlah SO berkenan juga diberi izin untuk dibekali diri dengan senjata api (senpi). Memang, hampir tidak ada bedanya. Yang beda, soal status mereka". (Hendrawan, Jawa Pos, 12 Desember 2001:26)

Menurut penulis kewenangan yang dimiliki dan diperbolehkan untuk dilakukan oleh petugas satpam di perusahaan hanya meliputi kewenangan phisik saja meskipun dalam hal-hal tertentu atau dalam hal tertangkap tangan diperbolehkan menangkap dan memborgol agar tidak melarikan diri dan menghilangkan barang bukti dan menanyakan hal-hal yang dianggap penting yang berhubungan dengan tindak pidana pelanggaran atau kejahatan yang telah dilakukan oleh pelaku di lingkungan perusahaan. Dengan demikian menurut penulis petugas satpam mempunyai tugas dan peran pembantu fungsi Polri sebagai tenaga keamanan yang mempunyai kewenangan dalam ruang lingkup kewenangan phisik yang sifatnya terbatas di perusahaan dimana petugas satpam bekerja.

\section{PENUTUP \\ Kesimpulan}

Petugas Satpam sebagai tenaga keamanan terbatas dalam melaksanakan tugas dan kewajibannya di perusahaan tempat kerjanya mempunyai peran sebagai pembantu fungsi Polri yang memiliki kewenangan pengamanan fisik yang sifatnya terbatas dan non justice sebagai keamanan dalam hal membina, mengarahkan, mencegah, menindak, dan menangkap serta memborgol apabila terjadi tindak pidana pelanggaran dan kejahatan yang tertangkap tangan di lingkungan perusahaan.

\section{Rekomendasi}

Maraknya tindak kejahatan pada saat sekarang ini peranan petugas satpam jangan sampai dilihat sebelah mata lagi, karena itu peran pemerintah dan instansi terkait di Bidang Ketenagakerjaan untuk mewajibkan kepada perusahaan yang mempergunakan jasa petugas satpam untuk diikutsertakan pendidikan dan pelatihan satpam sedangkan perusahaan yang akan mempekerjakan petugas satpam agar menerima yang telah mempunyai sertifikat satpam, sehingga keberadaan petugas satpam di perusahaan benar-benar dapat bergerak lebih cepat dan mengantisipasi sedini mungkin kemungkinan terjadi pelanggaran dan tindak kejahatan dan keberadaan petugas satpam di perusahaan dapat diandalkan.

\section{DAFTAR PUSTAKA \\ Buku:}

Arief, Barda Nawawi, 1998, Beberapa Aspek Kebijakan Penegakan dan Pengembangan Hukum Pidana, Cetakan Ke-I, Bandung: Citra Aditya.

Djumialdji, F.X., 2001, Perjanjian Kerja, Jakarta: Bumi Aksara.

Gunawan, Ilham, 1992, Penegakan Hukum dan Penegak Hukum, Bandung: Angkasa.

Muhammad, Abdulkadir, 1999, Hukum Perusahaan Indonesia, Bandung: Citra Aditya Bakti.

Rais, Moh. Lukman Tahillah, 1997, Tindak Pidana Perkelahian Pelajar, Cetakan Ke-I, Jakarta: Pustaka Sinar Harapan.

Satria, J., 1999, Hukum Pribadi Bagian I Persoon Alamiah, Cetakan Ke-I, Bandung: Citra Aditya Bakti.

Soemitro, Rony Hanintijo, 1998, Beberapa Masalah dalam Studi Hukum dan Masyarakat, Cetakan Ke1, Bandung: Remaja Karya. , 1975, Beberapa Permasalahan Hukum dalam Kerangka Pembangunan di Indonesia (Suatu Tujuan Sosiologis), Jakarta: Yayasan U.I. 
Soepomo, Imam, 1995, Pengantar Hukum Perburuhan, Cetakan Ke-XI, disunting Helena Purwanto dan Suliati Rahmat, Jakarta: Jambatan.

Subekti, R., 1981, Aneka Perjanjian, Edisi Ke-IV, Bandung: Alami.

Suseno, Franz Magnis Sj, Kees Bertens dkk., 1993, Etika Sosial, Cetakan Ke-III, Jakarta: Gramedia Pustaka Utama.

Weda, Made Darma, 1999, Kronik dalam Penegakan Hukum Pidana, Cetakan Ke-I, Jakarta: Guna Wijaya.

\section{Peraturan Perundang-undangan:}

Undang-Undang No. 9 Tahun 1998 tentang Kemerdekaan Menyampaikan Pendapat di Muka Umum, 2000, Bandung: Citra Umbara.

Undang-Undang Republik Indonesia No. 2 Tahun 2003 tentang Kepolisian, 2003, Bandung: Citra Umbara.

Undang-Undang Republik Indonesia No. 13 Tahun 2003 tentang Ketenagakerjaan. , Propenas 2000-2004, UU No. 25 Tahun 2000 tentang Program Pembangunan Nasional, 2001, Cet. Ke-1, Jakarta: Sinar Grafika.

Keputusan Menteri Tenaga Kerja dan Transmigrasi No. KEP. 229/MEN/2003 tentang Tata Cara Perizinan dan Pendaftaran Lembaga Pelatihan Kerja.

Keputusan Menteri Tenaga Kerja dan Tranmigrasi No. KEP. 225/MEN/2003 tentang Organisasi dan Tata Kerja Lembaga Akreditasi Lembaga Lembaga Latihan Kerja.

Peraturan Daerah Kota Surabaya No. 1 Tahun 2003 tentang Pelayanan di Bidang Ketenagakerjaan.

Peraturan Kepala Kepolisian Negara Republik Indonesia No. Pol.: 18 Tahun 2006 tentang Kurikulum dan Latihan Satuan Pengamanan.
Peraturan Kepala Kepolisian Negara Republik Indonesia No. Pol.: 24 Tahun 2007 tentang Sistem Manajemen Pengamanan Organisasi, Perusahaan dan/atau Instansi/Lembaga.

Surat Keputusan Kepala Kepolisian Negara Republik Indonesia No. Pol: Skep/1017/XII/2002 tentang Kurikulum Pelatihan Satuan Pengamanan.

Surat Keputusan Kepala Kepolisian Negara Republik Indonesia No. Pol: Skep/1018/XII/2002 tentang Pelatihan Satuan Pengamanan.

Surat Keputusan Kepala Kepolisian Negara Republik Indonesia No. Pol: Skep/1020/XII/2002 tentang Registrasi Satuan-satuan Pengamanan.

\section{Jurnal/Makalah/Majalah Kampus:}

Himpunan Materi Seminar, Peranan AMSI dalam Industrial Security, Sabtu 27 April 2002, Kerjasama Direktorat Binmas Polda Jatim.

Majalah Asosiasi Management Security Indonesia (AMSI), Edisi No. 01 Oktober 2002.

Majalah Asosiasi Management Security Indonesia (AMSI), Edisi 02 Maret 2003.

Security Guide Book, Pembinaan Satpam di Indonesia, 1994, Jakarta: Mabes Polri.

\section{Surat Kabar:}

Hendrawan, Praktis Tak Ada Biaya Tetek Bengek, Jawa Pos 12 Desember 2001.

, Dipecat, Kepala Satpam Harapkan Keadilan, Surabaya Sore, Senin Legi, 2 Agustus 2004.

, Pendeta Ditembak di Depan Jemaat, Jawa Pos, Senin 19 Juli 2004. , Perampok Bank Tembak Mati Polisi, Surya, Selasa Kliwon 13 April 2004. , Praktis dan Tak Ada Biaya Tetek Bengek (Aksi Teror dan Kriminal Marak, Perusahaan Security pun Banjir Order), Surya, 24 Juli 2003. 